\title{
SLOW MOVEMENT ON THE SLOPE
}

\section{On Architecture Principe's theory of the oblique function and the role of circulation in architectural and urban design}

\section{Christian Sander}

\section{Movement along the straight path or free exploration}

In 1977, Paul Virilio's book Speed and Politics ([1977] 2006) was first published in France with the subtitle Essai de dromologie (Essay on Dromology). The term "dromology" is a neologism derived from the Greek word dromos, meaning race or racecourse. According to Ian James, the theory deals "specifically with the phenomenon of speed, or more precisely, with the way speed determines or limits the manner in which phenomena appear to us" (2007, 29). Broadly speaking, Virilio's main hypothesis is that modern means of communication and transport are based on military technologies, the speed of which is fundamentally changing the global political geography in the sense that it produces a hegemony of "real time" to the disadvantage of "real space" (Virilio and Lotringer [1983] 2008, 230). In a conservation with Sylvère Lotringer in the early 1980s, Virilio stated:

Space is no longer in geography-it's in electronics. Unity is in the terminals. It's in the instantaneous time of command posts, multinational headquarters, control towers, etc. Politics is less in physical space than in the time systems administered by various technologies, from telecommunications to airplanes, passing by the TGV [French high-speed train], etc. There is a movement from geo- to chronopolitics: the distribution of territory becomes the distribution of time. The distribution of territory is outmoded, minimal.

(ibid., 126)

To discuss the connection between space and time, Virilio repeatedly referred to physics, particularly to Albert Einstein's special theory of relativity, based on which Hermann Minkowski, at the beginning of the 20th century, developed his theory of four-dimensional space-time. Virilio was often criticized for his free handling of 
scientific terminology; for example, he was one of the authors attacked by the physicists Alan Sokal and Jean Bricmont in their book Intellectual Impostures: Postmodern Intellectuals' Abuse of Science, first published in French in 1997 ([1997] 1998). In 1998, media scientist Kay Kirchmann published a "decidedly critical monograph" (1998, 7; own translation), in which he accuses Virilio of "methodical arbitrariness" (ibid., 9; own translation). However, he failed to look at Virilio's early work, which is not unimportant for an understanding of dromology. From 1963 to 1968, together with architect Claude Parent, Virilio formed the Architecture Principe group, which in its 1966 eponymous magazine - the group's manifesto-developed the theory of the oblique function. The idea was to design the building and the city exclusively using horizontal and inclined planes, on which the residents would have to exert themselves physically in order to get around (Figure 6.1). Architecture Principe's drawings show topographical architectural reliefs, so to speak, that were intended to generate new types of perceptual experiences and encounters.

In their contribution to this book, Martina Löw and Hubert Knoblauch emphasize the role of circulation in the refiguration of spaces. They point out the importance of traffic routes, for example, in Le Corbusier's utopian cities, which are divided into different functional zones by means of a geometric network of expressways. One

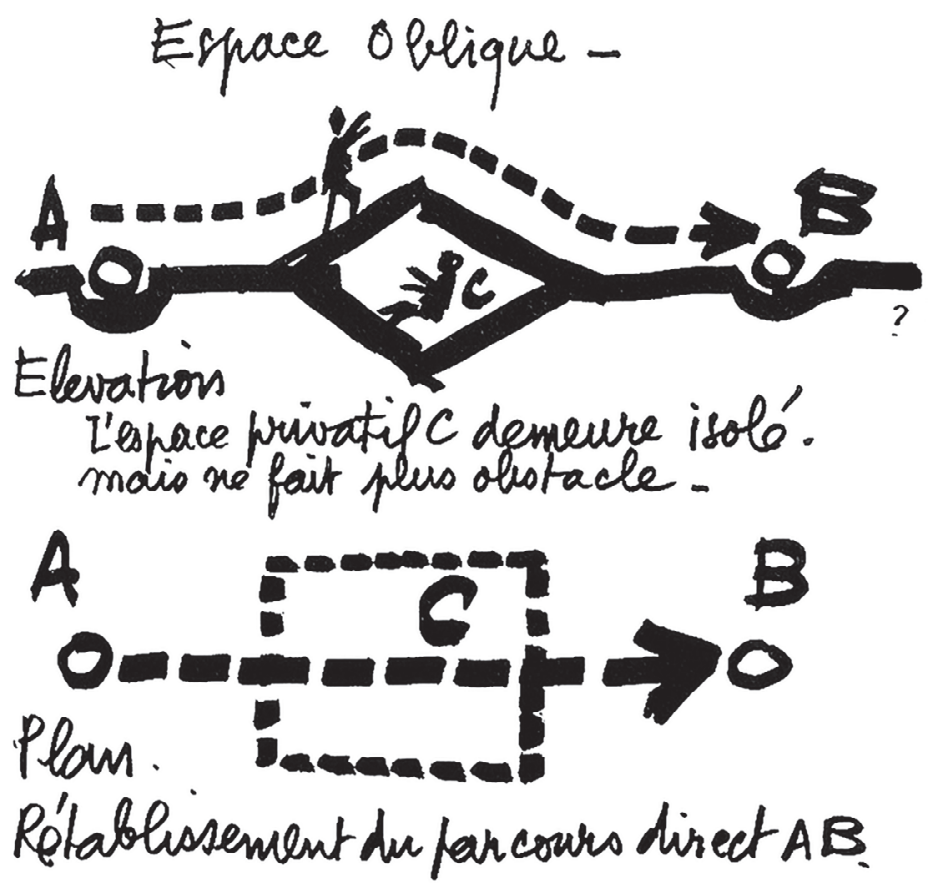

FIGURE 6.1 Claude Parent. Sketch illustrating the theory of the oblique function, the roof of the building becomes a pedestrian area, 1970

Source: Parent [1970] 2012. (C) Claude Parent Archives 
can also think of the famous quote from Urbanisme (Urbanism), Le Corbusier's urban design treatise from 1925: "The curved street is the path of donkeys, the straight street the path of men" ([1925] 1994, 10; own translation). For the speed critic Paul Virilio, however, the geometric organization of urban space, together with mediatization, leads to an alienation of the city dweller from his environment; this involves a temporary climax in the spatio-temporal organization of global air traffic:

when you look at Greek urban planning (the city of Miletus for example), colonial planning or that of the Roman camps, you see quite well that the roads are rectilinear. It's an organization of speed to drain the populations as fast as possible toward the city gates, toward the outskirts. A city is not simply a place where one lives, it's above all a crossroads. . . . This is why the airport today has become the new city. . . . People are no longer citizens, they're passengers in transit. ... The new capital is no longer a spatial capital like New York, Paris, or Moscow, a city located in a specific place, at the intersection of roads, but a city at the intersection of practicabilities of time, in other words, of speed.

(Virilio and Lotringer [1983] 2008, 77-78)

In November 1965, together with architecture critic Patrice Goulet, Claude Parent criticized Le Corbusier for making the pedestrian "a slave to the car" (1965, 2; own translation). With the oblique function, published a year later and focusing on the phenomenological body, the goal was to "reconnect" the city dweller with the physical urban space by forcing him to move around on foot. There should be no defined pathways on the sloping floors; in his short text "Pulsions" (Drives), published in July 1966 in the fifth issue of the Architecture Principe magazine, Parent writes:

The oblique function allows for travel. Architecture becomes the support of displacement; the movement is freed from the constraint and precision of the distance traveled, and the choice of the itinerary is left open. No longer is there canalization or constraint, but distance crossed and conquered; the human fluid can pulse at his own rhythm, upheld by the spatial structure, yet independent of the formal organization of the support.

(Parent [1966] 1997b)

The example of Architecture Principe's theory will be used in the following to further investigate the role of circulation, which refers to the movement of people in this chapter, in architectural and urban design. To do this, it is first necessary to take a look at the tradition of space-time in the first half of 20th-century architecture.

\section{Streamline architecture and the city dweller's haste}

The theory of four-dimensional space-time directly influenced the founders of modern art and architecture. In his book Space, Time and Architecture, first published in 1941, Sigfried Giedion writes about "unconscious parallelisms of method in science and art" (Giedion [1941] 1949, 14)—a statement that has already been 
put into perspective. The supposed space-time in art and architecture was mostly a matter of simplification or creatively misunderstood takeovers from the scientific debates of the time (Noell 2004, 308). Minkowski's theory was influential because the perception of space and time was indeed altered by the technical innovations of the 19th and early 20th centuries, especially modern means of transport. In 1914, architect Peter Behrens published the article "Einfluss von Zeit- und Raumausnutzung auf moderne Formentwicklung" (The Influence of the Use of Time and Space on the Development of Modern Form) in the yearbook of the Deutsche Werkbund (German Association of Craftsmen), which focused on city traffic.

This "development of modern form" became particularly evident in corner buildings. In reference to his redesign of the so-called Mossehaus in Berlin (Figure 6.2), to which he added additional floors and a new façade with a seemingly aerodynamic shape, Erich Mendelsohn stated in 1923:

the building is not a disinterested spectator of the rushing cars and of the advancing and receding flow of traffic; rather it has become an absorbing, cooperating element of the motion. The building both visibly encompasses in its overall expression the high speed of traffic, where the tendency toward motion is raised to an extreme, and at the same time the balances of its forces soothes the frenetic pace of the street and of the passersby. . . By dividing and guiding the traffic, the building, despite all tendencies of its own towards movement, becomes an immobile pillar amidst the turbulence of the street.

(Mendelsohn [1923] 1992, 28)

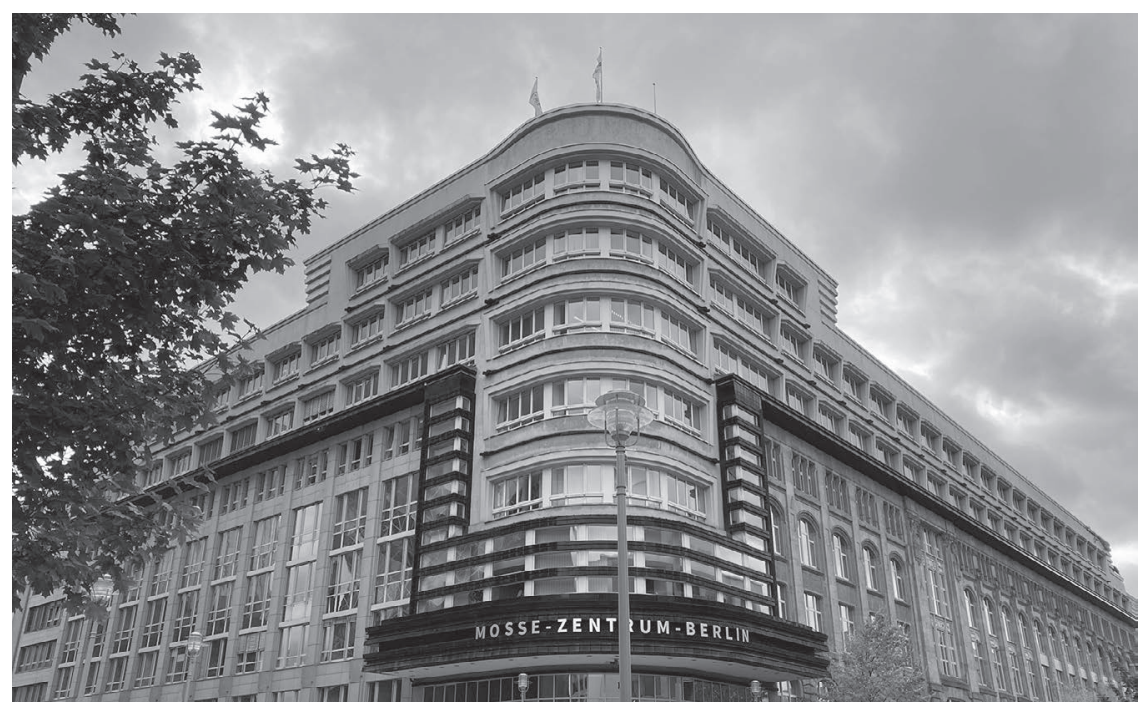

FIGURE 6.2 Erich Mendelsohn, Richard Neutra, and Paul Rudolf Henning. Renovation of the Mossehaus, Berlin, 1921-1923 
Thus, in order to "calm" the city dweller, according to Mendelsohn, one only has to balance the technologically enhanced speed with a "dynamic" architectural form. In his 1947 book Vision in Motion, in the subchapter "Speed" of the section "SpaceTime Problems," László Moholy-Nagy explains that one must clearly distinguish between the perception that is influenced by a means of transport and the perception when walking ([1947] 1969, 245-246). Another subchapter of this section is called "Mobile Architecture," in which the artist allows himself to be carried away into calling it "space-time reality." For example, he claims that Walter Gropius and Martin Wagner "are advocating demountable, movable houses for future cities" and that there "are projects not only of movable but of moving houses too; sanitariums, for example, turning with the sun” (ibid., 256-257). In his book, Moholy-Nagy celebrates the artist as a pioneer of developments in the technical-scientific field; for example, artistic experiments with positive and negative forms would have provided the basis for the design of streamlined products (ibid., 58-61). However, MoholyNagy makes it clear that he rejects the inflationary use of the streamlined shape:

The speed and motion of our period justify "streamlining." But streamlining was originally invented for moving objects and there is hardly any reason for an ashtray to be streamlined. Thus, when every product is blown up like a balloon-we have to fight against it, as formerly we did against the mechanical utilization of symmetry with which everything, in previous periods, could be made "harmonious and balanced."

(ibid., 34)

All quotes from Vision in Motion that have been cited here were published in French in 1950 in the fifth issue of the second series of Art d'Aujourd'hui (Art of Today). The art magazine was in a way the publication organ of the Espace (Space) group, an association of artists, designers, architects, and engineers founded by the painter Félix Del Marle together with the artist and editor André Bloc to promote the synthesis of the arts in the reconstruction of France after the Second World War. Before meeting Paul Virilio, Claude Parent was a member of Espace, where he mainly worked with Bloc and the sculptor Nicolas Schöffer. The latter, because he called for the integration of technology into art, can be seen as the exemplary artist of the Trente Glorieuses (The Glorious Thirty), the years between the end of the Second World War and the mid-1970s, which were characterized by economic prosperity and technological progress. In 1965, Schöffer was one of the founders of the Groupe International d'Architecture Prospective (GIAP) and, as such, primarily concerned himself with his project on a Ville cybernétique (Cybernetic City). This city model adopted a number of elements from the radical projects of the interwar period, for instance the division of the city into functionally differentiated zones, such as work and living. According to Schöffer, "man, caught in a spiral of acceleration and accumulated efforts, feels the need to differentiate his working environment from that of his residence" (Schöffer 1969, 100; own translation). Of course, in such a city, with great distances 
between work and home, fast means of transport are needed: in the drawing of the Ville résidence-dortoir (Commuter Town) (Figure 6.3), which is a part of the cybernetic city project, cars race past the elevated apartment buildings, which Schöffer designed together with Parent in the mid-1950s.

Parent shared Schöffer's opinion that architects and artists alike should open up to the latest technical developments. In his article "Les corps en mouvement" (Bodies in Movement), published in 1960, the architect formulated this conviction by referencing the streamlined shape:

It is said with enthusiasm in the art community that BRANCUSI'S sculptures preceded the appearance of aerodynamic forms. This fact, quite unverifiable, is extremely characteristic of what the world expects of the architect. It will be necessary to make the choice, to express it, to pronounce it by means of a form, which will no longer be only the consequence, the result of a sum of minor conditions, but rather an artistic choice, a choice on the part of a sculptor, who can act with the greatest degree of freedom, where the coefficient of penetration of a volume in the air will perhaps be one of the important elements guiding and exalting the research.

(Parent 1960, 6; own translation)

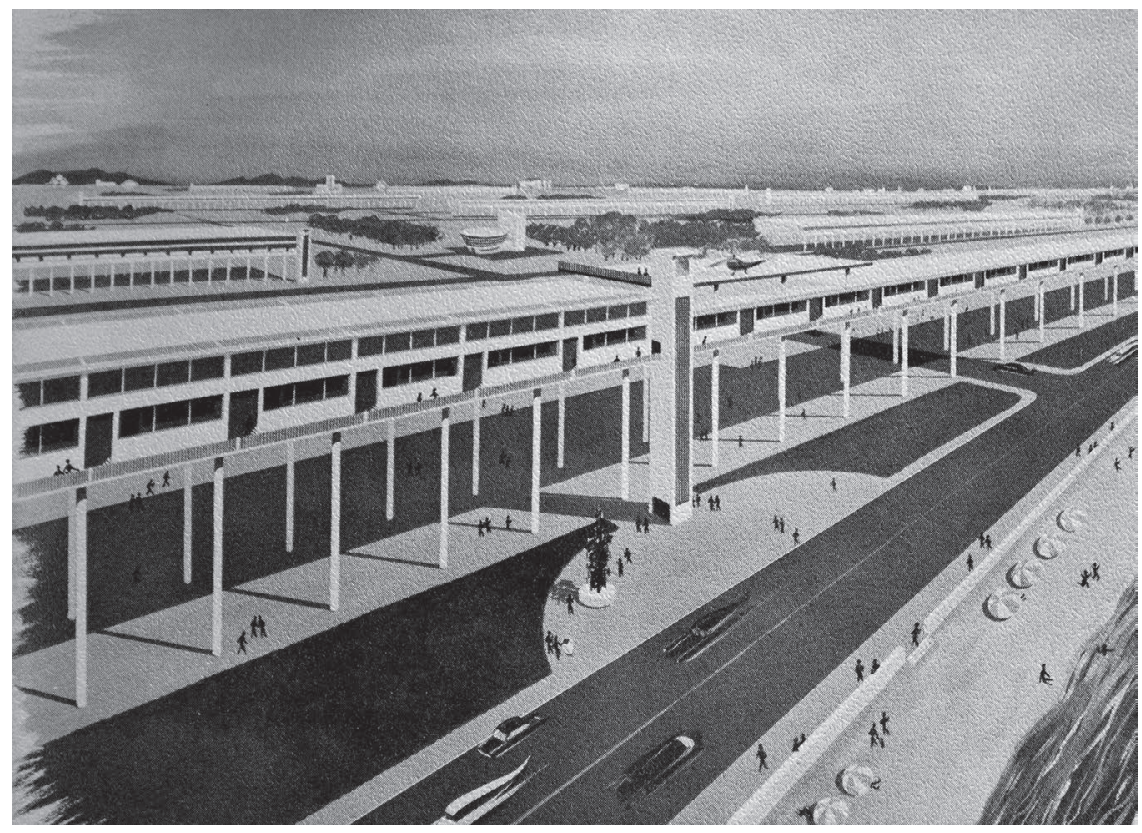

FIGURE 6.3 Nicolas Schöffer. Ville cybernétique, Ville résidence-dortoir (ville horizontale), around 1969

Source: Schöffer 1969. C VG Bild-Kunst, Bonn 2021 
Parent had very large structures that are exposed to strong winds in mind. Nevertheless, his own preoccupation with aerodynamics was limited to means of transport; later on, in his article, he discusses the shapes of cars, planes, ships, and trains.

\section{From the oblique function to dromology and the city of slow movement}

The collaboration with Paul Virilio, who was critical of technology as early as the 1960s, marked a turning point in Claude Parent's work. In a 1997 text on the oblique function, Virilio criticizes Nicolas Schöffer's cybernetic city project, in which the buildings are equipped with helicopter landing pads:

The heretical nature of this detour through the techniques of the body can be easily imagined, related to the problem of lodgings, that of a body having become self-moving again in contradistinction to prostheses of displacement of all sorts which had already invaded the city, waiting for the moment of the "cybernetic city" imagined at that time by Nicolas Schöffer.

(Virilio 1997, 11)

At the beginning of this chapter, it was pointed out that Virilio regularly emphasized the supposed military origins in modern means of transport - in "prostheses of displacement"-and communication devices. As an excerpt from the 1978 essay "Le monument irréel" (The Unreal Monument) on Erich Mendelsohn's Einstein Tower in Potsdam shows, he also recognized it in streamline architecture:

In the wake of the intensive production of dynamic (aerodynamic) means of transport by an arms industry that has essentially switched to the manufacture of means of transport and communication, architects have denatured the building, a static means of transport, in order to turn it into a dynamic (aerostatic) pseudo means of transport, as if the roofs and façades had suddenly turned into ship keels - recreating the ruins of this First World War, when the sky darkened with metallic thunder. Dramatic symbols of a disfigured, threatening space, the dissolution of the sky, and a premonition of those later storms in which the intense motorization of the crowds ultimately led to their deportation, in a "blitzkrieg" that saw Erich Mendelsohn flee from Nazi Germany after succumbing to the fateful lures of the Italian futurists.

(Virilio 1978, 366-368; own translation)

Thus, Virilio did not criticize streamlining for being decorative, as László MoholyNagy did. Rather, he used it as a representative example to highlight the alleged ubiquity of military structures. In a 1995 conversation with architect Enrique Limon, he clearly separated the two phases of his theoretical work-the Architecture Principe manifesto and the dromological writings - and even dismissed his collaboration with Parent as "a kid's game": "Groupe Architecture Principe was 
about space and politics whereas the issue of speed is about time and politics, which opens a whole new vista of research" (Limon and Virilio 1995, 184). What is problematic about this clear separation of space and time, however, is that Virilio, like the above-mentioned modern architects and artists, repeatedly referred to the theory of four-dimensional space-time and thus to the mutual dependence of space and time. What distinguishes Virilio's considerations from the enthusiasm felt by artists such as Nicolas Schöffer for machine-produced space-time phenomena is not the separation of space and time but rather the radical criticism of the devaluation of space by the technically enhanced speed as it is developed in the arms industry and then introduced into everyday life. This conviction forms the theoretical basis for Virilio's "whole new vista of research."

The main difference between the Architecture Principe manifesto and dromology is in fact that the latter presents a cultural pessimistic perspective, whereas the former develops an alternative model of architectural and urban design. For Parent, his membership in the Architecture Principe group was no less important. While the architect in the 1950s followed Nicolas Schöffer in his technological zeal and in 1960 even pleaded for an aerodynamic design of the architectural form, in his text "Le temps mort" (Time Out/Moribund Time), published in March 1966 in the Architecture Principe manifesto, he suddenly advocated a city for pedestrians:

The displacements in cities will be slow, their speed will be that of the pedestrian. The concern for speed will be found elsewhere, in other galaxies or in entertainment. Displacements necessary to life will become active. The notion of "wasted time" will disappear. Speed will no longer be necessary, nor a condition for survival.

(Parent [1966] 1997a, VI-VII)

Not just because of the capital letters, "Le temps mort" could also be taken for a chapter from one of Virilio's dromological essays:

We must first of all determine our position with respect to SPACE-TIME. Current thought in urban planning comes down to estimating geographical displacement in "units of TIME" instead of in units of linear measure proportioned to the displacement. We want nothing to do with this proposition based on "speed". We reject this view. Exploration in space invalidates and outdates the very notion of speed. In the new urban agglomerations, speed will not be considered a fundamental factor. It will no longer exist. As a result, the universe of aerodynamism will crumble.

(ibid., VI)

Parent stuck to this anti-speed stance after his collaboration with Virilio; in his book Entrelacs de l'oblique (Interlacing the Oblique), a kind of catalogue raisonné of his own work published in 1981, he continued to imagine the city of the oblique function as a pedestrian city in which vehicles should only be used to transport 
patients or deliver goods (Parent 1981, 30). This can be read in a chapter entitled "Phénoménologie du mouvement oblique et potentialisme" (Phenomenology of the Oblique Movement and Potentialism), which once again reveals the influence of Virilio, who in several interviews emphasized the impact of Maurice Merleau-Ponty's phenomenological philosophy on his thinking (Armitage and Virilio [1999] 2001, 15 and 18). Yet, the oblique city remained utopian, and in 1969, one year after the Architecture Principe group split up, the Concorde embarked on its maiden flight, capable of flying faster than twice the speed of sound. According to Virilio, it engendered "a deregulation of distance which causes time-distances to replace space-distances” (Virilio and Lotringer [1983] 2008, 74).

\section{Circulation translated into architectural form versus its fracturing by Architecture Principe}

While Nicolas Schöffer's cybernetic city project, due to its geometric organization for the effective (fast) movement of vehicles, can be regarded in line with the urban utopias of the interwar period like Le Corbusier's city projects, the oblique function must be understood as a kind of phenomenological countertheory to this technophilic approach of urban design (Busbea 2007, 7 and 160-167). Thilo Hilpert put it very clearly: "As an artificial relief, the city [of the oblique function, C.S.] should remain a physical space for movement and be accessible on foot, such that an archaic relationship to space is maintained despite the technical age" (Hilpert 1997/1998, 54; own translation). But circulation, that is, the movement of people in this chapter, is not just involved in the organization of the city; it also influences the shape of our built environment. With the car came the idea to design the buildings lining the road according to the perception influenced by the speed of the vehicle, and computerbased design now allows for even more elaborate ways to translate circulation into architectural form. In the 1990s, architect Greg Lynn used animation software from the film industry to document data such as wind movement, car traffic, and pedestrian flows in order to develop an animation from which he could generate a spatial structure (Ruby 2002, 42-43). For the Yokohama International Port Terminal, Foreign Office Architects (Farshid Moussavi and Alejandro Zaera-Polo) worked with a "no-return diagram" (Figure 6.4), that is, "a field of movements with no structural orientation." For the architects, this diagram was their "first attempt to provide the building with a particular spatial performance" (Moussavi and Zaera-Polo 2002, 11). The resulting pier can be described as paths turned into architectural form.

Due to its variously inclined surfaces, the Yokohama International Port Terminal was repeatedly associated with the theory of the oblique function (Bideau 2002, 17; Simonot 2010, 167). However, in Claude Parent's drawings of the church of Sainte-Bernadette du Banlay (Figure 6.5), built by Architecture Principe in the central French city of Nevers in the 1960s, the arrows do not represent the movement of people in the building. Here, it is the architectural form that, in the architect's drawing process, moves to finally become a spatial structure in which one is forced to find one's own way. When Architecture Principe designed the church, Parent was influenced by Hans Scharoun, whose Philharmonie in Berlin, with its 


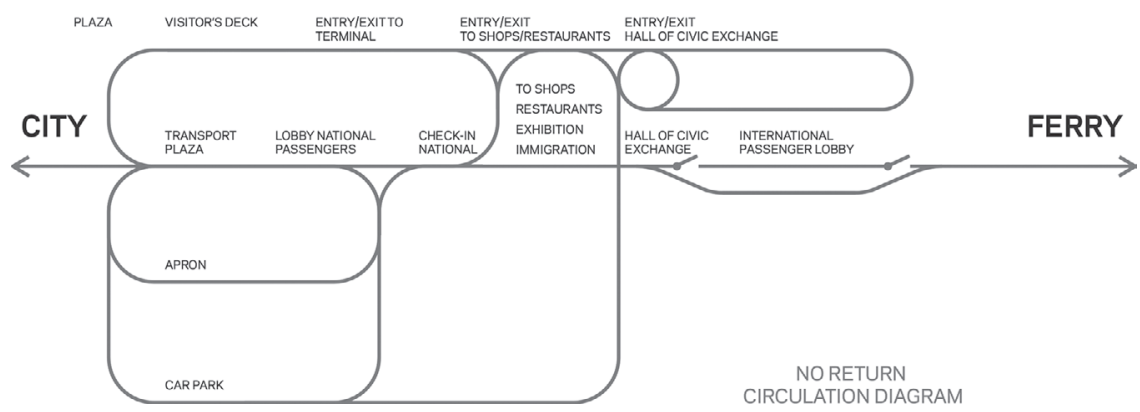

FIGURE 6.4 Farshid Moussavi and Alejandro Zaera-Polo (Foreign Office Architects, FOA). Yokohama International Port Terminal, no-return diagram, around 1995
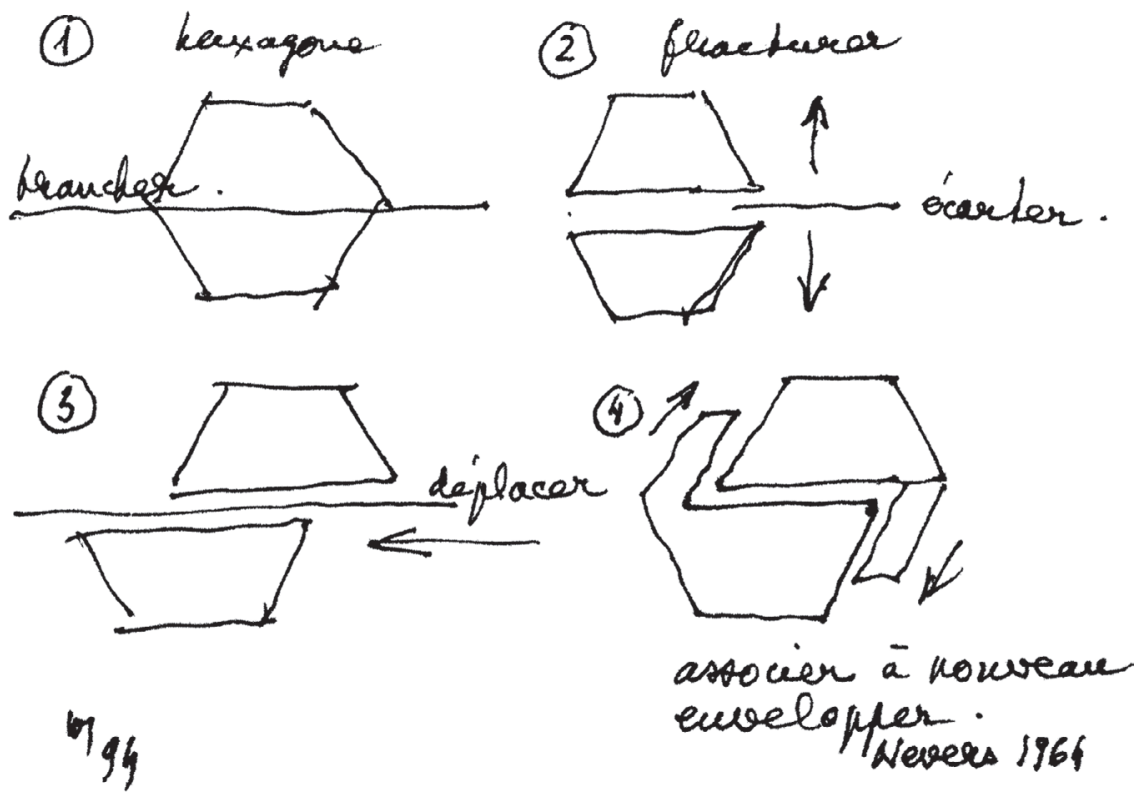

FIGURE 6.5 Claude Parent. Sketch illustrating the form-finding process for the church of Sainte-Bernadette du Banlay, built in Nevers in 1965/66

Source: Parent [1994] 2012. C Claude Parent Archives

highly complex plan, was built in the early 1960s. In a 1967 article, Parent writes about Scharoun's building: "In the interior spaces, one is at times faced with such a complex network of paths and circulation that one's attention is necessarily in a state of permanent alert" (Parent 1967, 38; own translation). It is this permanent alertness to our built environment that is taught to us in Architecture Principe's countertheory of the oblique function. 


\section{References}

Armitage, John, and Paul Virilio. (1999) 2001. "From Modernism to Hypermodernism and Beyond.” In Virilio Live: Selected Interviews, edited by John Armitage, 15-47. London: Sage.

Behrens, Peter. 1914. "Einfluss von Zeit- und Raumausnutzung auf moderne Formentwicklung." In Der Verkehr, edited by Deutscher Werkbund, 7-10. Jena: Eugen Diederichs.

Bideau, André. 2002. "Den Raum ergründen: Parent, Virilio und die Theorieplattform Architecture Principe." werk, bauen + wohnen 89 (11): 14-19.

Busbea, Larry. 2007. Topologies: The Urban Utopia in France, 1960-1970. Cambridge, MA: The MIT Press.

Giedion, Sigfried. (1941) 1949. Space, Time and Architecture: The Growth of a New Tradition. Cambridge, MA: Harvard University Press.

Hilpert, Thilo. 1997/1998. "Stadtvisionen der sechziger Jahre." ARCH+ 139/140: 50-57.

James, Ian. 2007. Paul Virilio. London: Routledge.

Kirchmann, Kay. 1998. Blicke aus dem Bunker: Paul Virilios Zeit- und Medientheorie aus der Sicht einer Philosophie des Unbewußten. Stuttgart: Verlag Internationale Psychoanalyse.

Le Corbusier. (1925) 1994. Urbanisme. Paris: Flammarion.

Limon, Enrique, and Paul Virilio. 1995. "Paul Virilio and the Oblique." In Sites \& Stations: Provisional Utopias: Architecture and Utopia in the Contemporary City, edited by Stan Allen and Kyong Park, 174-184. New York: Lusitania Press.

Mendelsohn, Erich. (1923) 1992. "The International Consensus on the New Architectural Concept, or Dynamics and Function.” In Erich Mendelsohn: Complete Works of the Architect, Sketches, Designs, Buildings, 22-34. London: Triangle Architectural Publishing.

Moholy-Nagy, László. (1947) 1969. Vision in Motion, Chicago: Paul Theobald and Company.

Moussavi, Farshid, and Alejandro Zaera-Polo. 2002. "Design Evolution.” In The Yokohama Project: Foreign Office Architects, edited by Albert Ferré, Tomoko Sakamoto, and Michael Kubo, 7-61. Barcelona: Actar.

Noell, Matthias. 2004. "Bewegung in Zeit und Raum: Zum erweiterten Architekturbegriff im frühen 20. Jahrhundert." In Raum-Dynamik: Beiträge zu einer Praxis des Raums/ Dynamique de l'espace: contributions aux pratiques de l'espace, edited by Franck Hofmann, Stavros Lazaris, and Jens E. Sennewald, 301-314. Bielefeld: transcript.

Parent, Claude. 1960. "Les corps en mouvement." Esthétique industrielle 46: 5-26.

Parent, Claude. 1967. "Scharoun ou l'espace dynamique." Aujourd'hui: Art et Architecture 57/58: 38-39.

Parent, Claude. 1981. Entrelacs de l'oblique. Paris: Éditions du Moniteur.

Parent, Claude. (1966) 1997a. "Time Out/Moribund Time." In Claude Parent and Paul Virilio. Architecture Principe: 1966 and 1996, VI-VII. Besançon: Les Éditions de l'Imprimeur.

Parent, Claude. (1966) 1997b. "Drives.” In Claude Parent and Paul Virilio. Architecture Principe: 1966 and 1996, XIV. Besançon: Les Éditions de l'Imprimeur.

Parent, Claude. (1970) 2012. Vivre à l'oblique. Paris: Jean-Michel Place.

Parent, Claude. (1994) 2012. Le Carnet de la fracture. Paris: Manuella Éditions.

Parent, Claude, and Patrice Goulet. 1965. "Le Corbusier: Architecture, urbanisme." Aujourd'hui: Art et Architecture 51: 1-95.

Ruby, Andreas. 2002. "Informierte Oberflächen: Kontinuität als Narration der Neunziger." werk, bauen + wohnen 89 (11): 39-45.

Schöffer, Nicolas. 1969. La Ville cybernétique, Paris: Tchou.

Simonot, Béatrice. 2010. "Claude Parent, présent dans la postérité/Claude Parent, Present in Posterity." In Nevers: Architecture Principe: Claude Parent, Paul Virilio, edited by Frédéric Migayrou, 162-169. Orléans: Éditions HYX. 
Sokal, Alan, and Jean Bricmont. (1997) 1998. Intellectual Impostures: Postmodern Intellectuals' Abuse of Science. London: Profile Books.

Virilio, Paul. 1978. "Le monument irréel." In Paris-Berlin, 1900-1933: Rapports et contrastes France-Allemagne, 365-371. Paris: Centre national d'art et de culture Georges Pompidou.

Virilio, Paul. 1997. "Disorientation." In Claude Parent and Paul Virilio. Architecture Principe: 1966 and 1996, 7-13. Besançon: Les Éditions de l'Imprimeur.

Virilio, Paul. (1977) 2006. Speed and Politics. Los Angeles: Semiotext(e).

Virilio, Paul, and Sylvère Lotringer. (1983) 2008. Pure War. Los Angeles: Semiotext(e). 